\title{
Tranzicijska preobrazba glavnih gradova Zagreba i Podgorice kao sustava naselja: bilateralni projekt između Hrvatske i Crne Gore (2015. - 2016.)
}

Institut za društvena istraživanja u Zagrebu, 2016., 249 str.

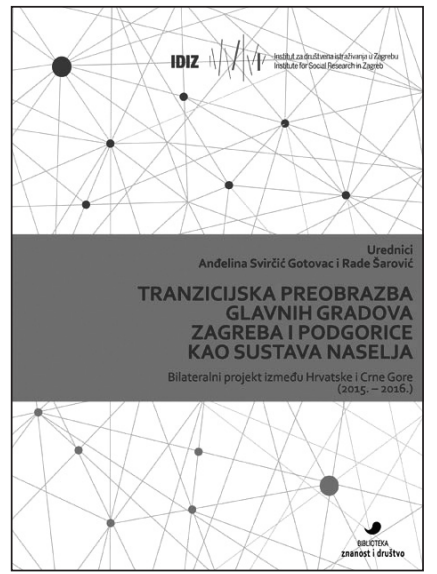

Knjiga Tranzicijska preobrazba glavnih gradova Zagreba i Podgorice kao sustava naselja: bilateralni projekt izmedu Hrvatske i Crne Gore (2015. - 2016.) nastala je kao rezultat istoimenoga bilateralnog znanstvenog projekta Hrvatske i Crne Gore. Projekt je realiziran 2015. i 2016. godine, nositelji su mu bili Institut za društvena istraživanja u Zagrebu (IDIZ) i Filozofski fakultet u Nikšiću, a urednici knjige bili su ujedno i voditelji istraživačkih timova, svatko u svojoj zemlji. Projekt su financijski podržala ministarstva nadležna za znanost u objema zemljama. Osnovni cilj projekta bio je opisati i analizirati društvene promjene u prostoru nastale u zadnjim dvama desetljećima u urbanim i suburbanim područjima glavnih gradova Hrvatske i Crne Gore, polazeći od pretpostavke da su promjene slične budući da se radi o gradovima i zemljama s vrlo sličnim povijesnim i društvenim karakteristikama. Ova knjiga posljednja je u nizu znanstvenih i stručnih radova IDIZ-a, čiji se stručnjaci promjenama u prostoru i istraživanjem kvalitete života bave još od 1970-ih.

Knjiga je podijeljena u ukupno osam poglavlja, koja zapravo predstavljaju osam znanstvenih članaka koji su sadržajno povezani i logično posloženi u cjelinu. S obzirom na činjenicu da je knjiga sastavljena od samostalnih znanstvenih članaka, logično je očekivati da u njima ima određenih preklapanja, posebno u teorijskim dijelovima. Dodatno, knjiga sadrži popisne podatke za Zagreb i Podgoricu, prilog s ukupno 24 fotografije koje prikazuju promatrana naselja i bilješke o svim autorima. U knjizi se prikazuju i isprepliću teorijski, metodološki i istraživački aspekti promatrane teme. Prvo poglavlje „Uvod u komparaciju urbanih prostora glavnih gradova Zagreba i Podgorice“, autorice dr. sc. Anđeline Svirčić Gotovac, pruža opis povijesnoga i društvenoga konteksta razvoja glavnih gradova dviju zemalja. U drugom se poglavlju pod nazivom „Urbani mega-projekti Podgorice i Zagreba u vre- 
menskim i prostornim dimenzijama crnogorskog i hrvatskog društva" autor dr. sc. Slobodan Vukićević bavi sociološkim implikacijama razvoja dvaju gradova. U trećem poglavlju, dr. sc. Rade Šarovića, tematiziraju se procesi deagrarizacije, urbanizacije i suburbanizacije, koji se provedenim istraživanjem dovode u vezu s promjenama u kvaliteti života na podgoričkom području. Četvrto poglavlje, autorice dr. sc. Jelene Zlatar Gamberožić, donosi rezultate kvalitativnoga istraživanja o aspektima urbane obnove u Zagrebu i Podgorici, a poseban se naglasak stavlja na nove aktere u urbanom prostoru. Dr. sc. Goran Ćeranić u petom se poglavlju bavi tranzicijskim promjenama u Podgorici te uspoređuje rezultate istraživanja o kvaliteti života provedenih u Zagrebu i Podgorici. Šesto poglavlje, autora Branimira Krištofića, stavlja tranzicijske promjene dvaju gradova u širi europski kontekst te raspravlja o povezanosti promjena društvenog uređenja i ekonomskog sustava s promjenama u prostoru. Sedmo poglavlje, čiji su autori dr. sc. Predrag Živković i Obrad Samardžić, govori o političkim promjenama u prostoru, odnosno utjecaju političkih promjena na promjene na gradskim ulicama i trgovima. Zaključno, osmo poglavlje zaokružuje cjelinu prikazom rezultata istraživanja u kojem su sudjelovali hrvatski i crnogorski stručnjaci za prostor, a u kojem su nastojali ustanoviti specifičnosti i nedostatke socioprostornih transformacija hrvatskoga i crnogorskoga društva.

Uvodno poglavlje, Anđeline Svirčić Gotovac, u prvom dijelu opisuje ciljeve bilateralnoga projekta i kontekst zbog kojeg je istraživanje značajno. Povlače se paralele između crnogorskoga i hrvatskoga društva i njihovih glavnih gradova. Iako su po broju stanovnika Zagreb i Hrvatska višestruko veći od Podgorice i Crne Gore, prepoznaju se slični trendovi u razvoju urbanih prostora dvaju gradova, a povijesni kontekst razvoja dviju postsocijalističkih i postjugoslavenskih zemalja također ima puno dodirnih točaka. Autorica ističe da se „procesi urbane obnove i revitalizacije specifični za postsocijalističke gradove pokazuju sličnima u obama istraživanim središtima grada“, a njihova je usporedba zanimljiva i u kontekstu procesa obnove gradova koja se provodila u duhu komercijalizacije javnih prostora i rastućim privatnim investiranjem u gradove i njihovu užu okolicu. Autorica potom donosi teorijski pregled svjetske i domaće literature koja promatra urbanu sociologiju, od Castellsa, Hamiltona i Zimmermana do Čaldarovića i Seferagić. U poglavlju se zatim uspoređuju podaci iz popisa stanovništva - zanimljivo je da cijela Crna Gora ima značajno manji broj stanovnika od Grada Zagreba, a njihova komparacija u urbanoj sociologiji ipak ima smisla. Ono najvažnije što je zajedničko Hrvatskoj i Crnoj Gori u kontekstu urbane sociologije jest prekomjerna centraliziranost. U poglavlju se ukazuje na to da dvije zemlje umjesto razvijanja policentričnog sustava po uzoru na razvijene zapadne zemlje i dalje idu putem centralizacije.

Slobodan Vukićević u svome članku (drugo poglavlje knjige) polazi od pretpostavke da razvoj glavnih gradova Zagreba i Podgorice kao megaprojekata ima bitan utjecaj na dinamiku i strukturu ukupnoga, urbanoga i ruralnoga prostora hrvatskoga i crnogorskoga društva. Autor ističe i da, gledano idealtipski, razvoj takvih megaprojekata ima svoje pozitivne i negativne sociološke posljedice. U poglavlju se potom kroz slikovite primjere opisuje tijek centralizacije Crne Gore u razdoblju socijalizma, u kojem se nije smjelo dozvoliti da neki drugi grad dobije veći značaj od Titograda (današnje Podgorice). Nakon toga, u periodu tranzicije, centralizacija se u objema ze- 
mljama nastavlja, ali dominantnu ulogu u procesima prostornog razvoja preuzimaju ekonomski akteri vođeni uglavnom isključivom logikom profita. Međutim, u obama je društvima već duže vrijeme prisutna svijest da ostvarenje megaprojekata glavnih gradova nije pridonijelo kvaliteti života u gradovima. Naprotiv, kvaliteta je života u njima, prema svim istraživanjima pa i ovome, stagnirala, a u nekim se aspektima čak i smanjivala. Poglavlje završava zaključkom u kojem se ističe povezanost vremena i prostora u razvoju gradova te poentira da stvaranje megagradova uvijek ima i pozitivne i negativne posljedice na društveni život zemalja u kojima se provodi.

U trećem poglavlju Rade Šarović bavi se suburbanizacijskim procesima i kvalitetom života u podgoričkoj mreži naselja. U prvom dijelu objašnjava kontekst procesa deruralizacije, deagrarizacije i industrijalizacije Crne Gore, koji su doveli do povećanja značaja glavnog grada. Autor posebnu pažnju posvećuje i procesu suburbanizacije, koji se u Crnoj Gori intenzivirao između 60-ih i 80-ih godina 20. stoljeća, a značio je premještaj seoskog stanovništva u blizinu gradova i posljedično propadanje i demografski debakl crnogorskih sela. Šarović današnju Crnu Goru ocjenjuje kao „djelomično razvijeno urbano društvo izraženih regionalnih nejednakosti“, čemu su pridonijeli navedeni procesi u socijalizmu, ali i postsocijalistička transformacija društva i prostora. Autor potom predstavlja rezultate empirijskoga istraživanja o kvaliteti Života u Podgorici i okolici. Zaključci istraživanja govore da je današnja Podgorica heterogena cjelina, u kojoj se prepoznaje „niz problematičnih specifičnosti“. Sela u podgoričkoj mreži naselja infrastrukturno su loše opremljena, pri čemu se ističe problem manjka adekvatne zdravstvene zaštite stanovnika zbog nepostojanja ambulanti. Također, kulturni se život u područjima izvan centra Podgorice praktički ne odvija zbog nepostojanja društvenih centara i kulturnih ustanova. Problem u prigradskim naseljima predstavlja i sve veća pojavnost nelegalne izgradnje. U samom gradu stanovnici imaju sve potrebne sadržaje za zadovoljenje društvenih potreba, ali njihovo zadovoljstvo kvalitetom života ipak nije potpuno. Preoblikovanje centra grada, devastiranje kultnih mjesta radi izgradnje novih sadržaja i smanjenje broja istinski javnih prostora problemi su koje su stanovnici Podgorice u svojim odgovorima najviše isticali.

Autorica Jelena Zlatar Gamberožić u četvrtom poglavlju analizira aspekte specifičnih oblika urbane obnove i revitalizacije u Zagrebu i Podgorici. Rad se koncentrira na drugu fazu promjena, nakon 2000. godine. I ovaj članak (poglavlje) u prvome dijelu nudi pregled teorijske građe o postsocijalističkim društvima i gradovima te o aspektima urbane obnove i revitalizacije. Urbana revitalizacija definira se kao pokušaj vraćanja života u degradirane dijelove grada kroz suradnju svih ključnih aktera u urbanom prostoru (ekonomskih, političkih, stručnih, civilnih). Potom se objašnjavaju konteksti razvoja Zagreba i Podgorice, pri čemu su registrirane ključne promjene u gradovima. To su: stvaranje novih prostora produkcije/konzumacije uvjetovano globalizacijom i ekonomskim restrukturiranjem, socijalna diferencijacija u stambenim prostorima povezana $s$ rastom nejednakosti i novim oblicima urbanog siromaštva te konfliktni i selektivni urbani razvoj povezan s novim modelima vlasti i institucionalnih transformacija. U poglavlju se zatim prezentiraju rezultati istraživanja provedenoga metodama fokus-grupa i polustrukturiranih intervjua $s$ različitim stručnim akterima. U Zagrebu su prepoznati sljedeći ključni aspekti urbanog planiranja: 1. 
lokacijski, neplanirani, „investitorski“ urbanizam; 2. smanjivanje uloge urbanističkog planiranja; 3. narušavanje odnosa privatnoga i javnoga prostora u korist privatnoga; 4. preizgradnja; 5. pokoravanje arhitekture tržištu i 6. novi urbani akteri i promjene u odnosima moći među njima. U Podgorici su prepoznati isti ključni elementi, s tim da se ondje pojavio i problem gubitka identiteta grada. Istraživanje je potvrdilo da su se odnosi moći među akterima u urbanom prostoru promijenili u korist ekonomskih i političkih aktera, te da se urbano planiranje i stručni pristup urbanizaciji sve više guraju na društvenu marginu.

Peto poglavlje, Gorana Ćeranića, ima za cilj usporediti rezultate istraživanja kvalitete života provedenih u zagrebačkoj mreži naselja 2014. i podgoričkoj 2015. godine. U prvom se dijelu tematizira socijalistički i postsocijalistički period razvoja društava bivše Jugoslavije i razvoj urbanizma u tim periodima. U istraživanju se kvaliteta života operacionalizira kroz tri ključna kriterija: 1. materijalni prihodi, koji su osnovni uvjet osiguravanja dobara koja predstavljaju osnovu životnog standarda; 2. stanovanje, kod kojeg su važna obilježja stambeni status, lokacija, veličina i broj soba; 3 . opremljenost domaćinstva, koja se mjeri posjedovanjem instalacija, pomagalima u kućanstvu i luksuznim dobrima. Rezultati provedenog istraživanja pokazali su mnoge sličnosti kvalitete života u Zagrebu i Podgorici kada su u pitanju karakteristike stanova i opremljenost domaćinstava. Najveće je odstupanje u domeni prihoda; zagrebačka domaćinstva imaju prosječno kudikamo veće stalne i dodatne prihode od podgoričkih. Navedeni podatak nije neočekivan jer je ekonomski standard u Zagrebu uvijek bio veći od onoga u Podgorici, od socijalizma naovamo. Dodatno, velike su razlike u kvaliteti života prisutne unutar i zagrebačke i podgoričke mreže naselja, što pokazuje da je klasna diferencijacija dobila i svoj prostorni odraz.

U šestom se poglavlju autor Branimir Krištofić bavi širim europskim značajem urbanih promjena te ih stavlja u kontekst dominantnih društvenih vrijednosti i ekonomskih uređenja. Predstavlja zanimljive teze britanskog geografa Martina Sokola, koji je ustvrdio da je tranzicija Istočnoj Europi donijela „raspad tržišta, ekonomski pad, visoku nezaposlenost, inflaciju, sumnjivu privatizaciju, opći pad standarda i socijalnu polarizaciju“ te, na političkom planu, „političku fragmentaciju i nestabilnost, poteškoće s uspostavom demokratskih institucija, uzdizanje nacionalističkih pokreta i prijetnje manjinama“. Postsocijalističke zemlje, u koje spadaju i Crna Gora i Hrvatska, Sokol je nazvao superperiferijom. Dalje u poglavlju Krištofić navodi eklatantne odraze promjene ekonomskog sustava u prostoru - velike šoping-centre okružene stambenim naseljima bez adekvatne javne infrastrukture i zelenih površina, kakvi su i u Podgorici i u Zagrebu nikli nakon „demokratskih promjena“. „Pravog urbanizma više nema", ističe autor. Nakon toga usporedno analizira uvjete života i stanovanja u europskim državama i uzima pritom u obzir da su Hrvatska i Crna Gora u svjetskom kontekstu zemlje u kojima je kvaliteta života visoka. Pa ipak, te su zemlje i njihovi glavni gradovi i dalje na periferiji Europe po ekonomskim i društvenim pokazateljima. Pomicanje sa superperiferije Europe na periferiju Europske unije nije zasad u tom smislu donijelo značajne pomake.

Obrad Samardžić i Predrag Živković u sedmom se poglavlju bave simboličkom teksturom postsocijalističke transformacije urbanih prostora. Dramatične promjene na 
kraju 20. stoljeća donijele su oblikovanje jednog novog društvenog konteksta koji predstavlja revolucionaran raskid s „mrskim“ vremenom socijalizma, a kada su u pitanju promatrane zemlje radi se o raskidu s jugoslavenskom idejom i (re)aktivacijom nacionalnih politika. Dok je pad Berlinskog zida u svijetu značio rušenje zidova, na ovom je prostoru uzrokovao podizanje novih zidova. Radikalne promjene političkog sustava donose promjene simboličkog identiteta, što se najslikovitije vidi u javnom prostoru. Sa slomom socijalizma počinje proces razgradnje simboličkih tekovina koje je taj sustav utkao u urbani prostor te istovremeno stvaranje „novog lica“ nacije. Najbolje se to vidi na promjenama imena gradskih ulica i trgova. Prema nalazima istraživanja, u Zagrebu je od 1990. do 2007. preimenovano 474 ulica i trgova, a promjene su bile najintenzivnije odmah po uspostavljanju samostalne Hrvatske. Iz naziva ulica i trgova nestaju narodni heroji socijalizma, važni datumi, vrijednosti koje su simbolizirale sustav (bratstvo i jedinstvo, proletarijat), geografska imena iz ostalih zemalja bivše države. Ta imena zamjenjuju se novim, „hrvatskijim“ imenima, za što se u članku daje niz primjera. U Crnoj Gori takve su se promjene, zbog različitih povijesnih okolnosti, počele dešavati mnogo kasnije, tek 2004. godine nakon razlaza sa Srbijom. Ali ni nakon toga nisu bile ni približno toliko dramatične kao u Zagrebu, pa je Podgorica danas jedini grad bivše Jugoslavije koji ima ulice s nazivima svih ostalih glavnih gradova bivše države. U poglavlju se zaključno donosi analiza društvenih i ekonomskih promjena i njihova utjecaja na razvoj gradova, ali i sve veći „histerični manirizam" potrošnje i tržišne ranjivosti.

Zaključno, osmo poglavlje knjige sumira rezultate istraživanja provedenog u sklopu projekta. Analiziraju se ponovno i teorijski okvir i tranzicijski kontekst te prostorno povezivanje sustava naselja Zagreba i Podgorice. Tranzicijsko širenje gradova prema okolnim prostorima redefinira pojam grada, koji danas uključuje naselja različitih profila, a urbani prostor postaje sve umreženiji. Nadalje se u poglavlju prezentiraju rezultati fokus-grupa sa stručnjacima za prostor provedenih u Zagrebu i Podgorici. Odgovori stručnjaka jako su zanimljivi i imaju puno dodirnih točaka u dvama gradovima. Grupirani su u tri dimenzije: odgovori o trenutnom stanju razvoja prostora, odgovori o novim urbanim akterima i odgovori o novoj poslovnoj i stambenoj gradnji. Zaključuje se da je trenutno stanje nezadovoljavajuće, da ekonomski akteri igraju ključnu ulogu u formiranju prostora, dok se savjete stručnjaka ne uzima dovoljno u obzir, a prepoznaju se slični obrasci izgradnje u obama gradovima, posebno kad su u pitanju poslovni objekti kao što su šoping-centri. I Zagreb i Podgoricu obilježavaju i procesi centralizacije i hijerarhizacije. Stoga se zaključuje da je najveći gubitnik tranzicije upravo prostor, i urbani i ruralni. Prikaz zbog toga možemo završiti citatom stručnjaka koji je sudjelovao u fokus-grupi: „Sličniji smo nego što mislimo, barem po količini gluposti“. 